\title{
A Philosophical Examination of the Traditional Yoruba Notion of Education and its Relevance to the Contemporary African Quest for Development
}

\author{
Ademola Kazeem Fayemi \\ Department of Philosophy \\ Lagos State University, Nigeria \\ kcaristotle@yahoo.com \\ and \\ O.C. Macaulay-Adeyelure \\ DEPARTMENT OF PHILOSOPHY \\ Lagos State University \\ wunmi_makay@yahoo.com
}

Thought and Practice: A Journal of the Philosophical Association of Kenya (PAK)

New Series, Vol.1 No.2, December 2009, pp.41-59

thoughtandpractice@gmail.com OR thoughtandpractice@uonbi.ac.ke

\begin{abstract}
This paper undertakes a philosophical investigation of the implications of the traditional Yoruba understanding of education for the contemporary African quest for development. The paper argues that the Yoruba conception of education is marked by the underlying philosophical principles of functionalism, moralism and progressivism. These principles, the paper contends, are of great relevance to the quest of contemporary African societies for education that will serve as a catalyst for development.
\end{abstract}




\section{Introduction}

This paper proceeds from four presuppositions. First, quality education is a sine-qua non of sustainable development in any society. Second, there is a conception of education among the Yoruba of Nigeria, different from the Western or contemporary African understanding of it. Third, there is a crisis of development in contemporary African states, which has assumed various dimensions and received wide scholarly interest in search of alternative solutions. Fourth, education in many parts of Africa today, and especially in Nigeria, mirrors the deplorable state of affairs in the society: this last contention is in consonance with the research finding of Kalusi, who notes that "like many aspects of the social and economic life of Nigeria today, education is immensely in crisis" (Kalusi 2007, 4).

The paper seeks to establish two central positions: first, there is an urgent need for a viable philosophy of education that can serve as praxis in the pursuit of educational goals, and drive the multi-dimensional wheel of development in Africa. Second, there is a nexus between tradition and modernity, and as such, the traditional Yoruba notion of education can complement other relevant ideas in providing a conceptual framework for the contemporary African quest for development.

In pursuit of the theses above, the discussion is divided into four sections. The first section interrogates the traditional Yoruba notion of education. The second section is an exploration of the philosophical basis of traditional Yoruba practice of education. The problem of development in Africa as well as the crisis in the educational system is contextualized in the third section of the paper. A philosophical examination of the relevance of the traditional Yoruba notion of education to the quest for development in $21^{\text {st }}$ century Africa is undertaken in the fourth section of the paper, before some concluding remarks are made.

\section{The Traditional Yoruba notion of education}

One of the major ethnic groups in Nigeria, West Africa, is the Yoruba, who occupy the South-West states of the country (Ogun, Lagos, Ondo, Oyo and Ekiti), mainly, and some parts of Kwara and Kogi states in Northern Nigeria. Apart from Nigeria, the 
Yoruba are also found in sizeable numbers in the Southeastern part of the Republic of Benin, Togo and Dahomey in West Africa, in West India and in South Africa (Balogun 2009, 1).

While the Yoruba can be found in different parts of the globe, a thriving Yoruba culture can be found in South America and the Caribbeans, especially Brazil and Cuba, where the descendants of the unwilling immigrants to the new world have been able to maintain their identity and preserve their cultural heritage (Gbadegesin 1991, 174). The Yoruba, in general (that is, those that have their ancestral home in Nigeria and those in the Diaspora) have a rich cultural heritage rooted in their traditional modes of thought.

One of the most cherished values of the traditional Yoruba, which shaped their thinking patterns and behavioural dispositions, is education. This might sound bizarre at first, especially taking into consideration the popular "uneducated" picture of the Africans painted by the early Western anthropologists in Africa, and the consequent claim of a "civilizing" agenda of the erstwhile colonial lords. The wild claims about traditional African societies (the Yoruba inclusive) by some Western scholars and anthropologists are to the effect that the people are "primitive", and therefore uneducated. For specific illustrations, it is important to cite some of the claims of Western colonial researchers, which are neither corroborated by ethnographic proofs nor by the evidence of history.

According to Robin Horton, the traditional African mode of thought was "closed" because it was typified by "the absence of vision of alternatives", and Africans were "unreflective" in their thinking (Horton 1970, 154). Levy-Bruhl had once seen in the African a category of primitive mentality - a being with a pre-logical mind at ease in mysticism and magic, and governed by the law of participation rather than by logical canons. Africans, he said, "live in the dream world; they are not logical, and as a result their assertions are full of logical contradictions (Levy-Bruhl 1967, 21-23).

Hobbes claimed that "Africa is a timeless place in which there are no art, letters or social organization". Said Rousseau, "the black people are unable to think in any reflective manner. Their engagement in arts is therefore, a thoughtless activity, which is an anti-thesis of the intellect" (cited in Oluwole 2006, 14). All these Western 
scholars' claims presuppose that the typical traditional African was not educated. Apart from the fact that the claims, when considered separately and collectively, entailed denigatory, ethnocentric biases and under estimation of the dignity of the traditional Africans, the claims have some connections with the colonial agenda. The assertions were made to provide intellectual legitimacy to the colonization of Africa, and to extenuate the arguments for the ills of colonization, which is premised on the civilizing mission of the caucasoid race. This mission to civilize Africans from the debris of "primitiveness" led to the introduction of Western religion and education to the Africans. Thus it is clear that at a point in the course of Africa's history, the European intelligentsia believed that traditional Africans had no concept of education.

Contrary to the colonial assumption about the traditional Africans, this paper argues that the traditional Yoruba had an indigenous conception of education before their contact with the West. Against the hitherto cited anthropologically and ethnocentric view, we shall contend that the traditional Yoruba had a different conception of education from the Western understanding of it. Our purpose for exposing such a hitherto ignored and vilified conception is not to ethno-philosophically eulogize the traditional past as glorious. Nor is it to compare the indigenous Yoruba notion of education with the Western conception of it in terms of a superiority-inferiority dichotomy. Rather, our aim of exposing this indigenous Yoruba understanding is to philosophically argue that such a conception of education must not be dismissed in its entirety, as there are some relevant insights that contemporary African societies can learn from the indigenous conception in the endeavour to make education a tool for development.

Education, for the traditional Yoruba, is a life-long process. Education is seen by them as any act or experience that has an integrative and formative effect on the mind, character, skills, physical and spiritual abilities of the individual to enable him/her live effectively and responsibly in the society. In consonance with the Yoruba understanding, Babatunde Fafunwa defines education as "the aggregate of all the processes by which a child or young adult develops abilities, attitudes and other forms of behaviour, which are of positive value to the society in which he lives" (Fafunwa 1982, 17). 
The word "education" in Yoruba is eko. The word eko has a broader meaning than imo (knowledge), ogbon (understanding), iwe (literacy), ile-iwe (schooling) and oye (wisdom). Though not unrelated, the word eko means the actual display and consistent demonstration of the epistemic features of knowledge, understanding, wisdom and other ethical values of excellence in character, honesty and modesty in attitude, and self-restraint in action and expression.

For the traditional Yoruba, to be adjudged educated is not merely a question of being literate, bookish and having prowess in Arithmetic and the Queen's English. It goes beyond that, and this perhaps accounts for the Yoruba proverb that - iwe ki $n$ se ogbon, a le jo ikun ni (literacy is not wisdom, but only an addendum to already acquired knowledge) (Balogun 2008, 124). This proverb is not discountenancing school and literacy: it is only saying that literacy is not sufficient for obtaining further information and for modifying attitudes and behaviour. It can be deduced from the proverb that for the Yoruba, it is not only those who have been to school that can be educated (Akinpelu 1987, 183).

The Yoruba distinguish between the concepts of abiiko (born but not educated) and akoigba (one who refused to be educated) in their notion of education. In the case of the former, the child naturally lacked the avenues of being well nurtured and trained, especially by the first set of teachers, who are the parents. In the latter case however, the responsibility for not being educated is the individual's rather than that of the parents and society at large.

Both abiiko and akoigba are regarded by the Yoruba as omokomo (a worthless child). Nothing mortifies a person in the Yoruba cultural setting more than being referred to as omokomo - a person who lacks education, that is, cultural training in character and actual demonstration of such training in attitudes and deeds. The failure of serious intervention in the educational lapses of omokomo and the consequently transitory passage into adulthood earns the appellation, agbaiya (the elder who behaves like an untutored child). Such an adult has no integrity: he is untrustworthy, unreliable and lacks people's confidence. He is referred to as eniyan la san, that is, "caricature person". 
The traditional Yoruba recognized the possibility of educational improvement in the transitory stages of childhood to adulthood. Where such expected cultural education was lacking, the transposition from omokomo (worthless child) to agbaiya (the elder who behaves like an untutored child) and is consequently eniyan la san ("caricature person") is automatic. Nevertheless, where education was present, such causal links could be truncated. Thus for the Yoruba, education was a life-long process involving interconnections among different experiences that had formative and integrative effects on the entire personality of an individual in relation to his/her society.

The traditional Yoruba notion of education can be appropriately understood only in relation to the concept of omoluwabi. There are different interpretations given to the word omoluwabi in Yoruba literary discourse. Without unnecessarily delving into this controversy, we conceive an omoluwabi as a good person of integrated personality, who demonstrates fairly well the positive use of the mental, physical and psychological features of the human person, as well as moral uprightness in his/her life in society. Literarily and semantically, omoluwabi, according to Sophie Oluwole's interpretation (which we agree with), is a phrase that means omo to oni iwa bi...? ("a child whose character takes after....who?") (Oluwole 2007,12). In giving a full rendition of this interrogative phrase, Oluwole noted that for the Yoruba, "omoluuabi means omo ti o ni iwa bi eni ti a ko, ti o si gba eko (a person (child) [sic] who behaves like someone who is nurtured and lives by the precepts of the education he/she has been given)" (Oluwole 2007, 13).

The upshot of the observations above is that omoluwabi denotes a person who has been nurtured in accordance with societal values. He has deep knowledge and skill in certain areas of life, and develops a sense of responsibility to the society, which is evidently shown in private and public actions. All these attributes earn him/her respect in the society. It is in line with this understanding that T.A. Awoniyi (1975, 364) observed that "the end-product of education in Yoruba culture is to make an individual, an omoluwabi." In the same vein, Majasan (1967) asserted that the principles of Yoruba education are based on the concept of omoluwabi. Conceiving of an omuluwabi as a person of good character in all its ramifications, Majasan said by good character, the Yoruba meant "respect for old age, loyalty to one's parents and local traditional honesty in all public and private dealings, devotion to duty, readiness 
to assist the needy and the infirm, sympathy, sociability, courage and itching desire for work and many other desirable qualities" (Majasan 1967, 37).

While we can add such attributes as oro siso (intelligent and expert use of language/utterances), inu rere (having good intent towards others), otito (truth), opolo pipe (intelligence) and iwapele (gentle character/self restraint) as parts of the other desirable qualities expected of an omoluwabi in Yoruba culture, we need to correct two superfluous assumptions implicit in the positions of Awoniyi and Majasan on the role of the concept of omoluwabi in the Yoruba notion of education.

First, Awoniyi and Majasan's concept of omoluwabi seems to convey a picture of an ideal person in the Yoruba cultural milieu. However, we should note that an omoluwabi is not a person of impeccable character or an iron cast with no flaws. This is because the Yoruba abhor all claims of absolutism, and believe that as humans we can only, and ought to, strive towards the ideal, because perfection is illusory (Fayemi 2009a, 171). Second, we can glean from the analysis of Awoniyi and Majasan the impression that the central principles of education among the Yoruba boil down to their conception of omoluwabi, and that indeed, the end-product or aim of education among the Yoruba is to make an individual into an omoluwabi. This position is exaggerated and it is incongruent with the Yoruba authentic notion of education.

For the Yoruba, education is in stages, and it is a continuous process of positive learning from experiences that man encounters in his daily living. Understood as such, attaining the status of omoluwabi is not the end in view. It is not guaranteed that omoluwabi will continue to stay as a model of character. For omoluwabi to continue to excel in character, education has to be in place. As a young adult, when one attains the status of omoluwabi, the Yoruba refer to him/her as omogidi (a genuine child). An omogidi is responsible as a youth, knows his/her place in society, respects the wisdom of the elders, participates actively in communal duties, and is an idol of his/her group. Yet, it is not uncommon that the next stage of an omogidi's life may see him/her transform into an agbaiya (the elder who behaves like an untutored child) an eventuality caused by the absence of appropriate continuous cultural training (Gbadegesin 2007, 87). 
Because education is a lifelong process among the Yoruba, the transition from the position of omogidi to the next rank earns a person the title of agbasanko. "Agbasanko is the seasoned elder, the one that everyone wants to emulate; the one that has dignity and integrity; the one that commands respect" (Gbadegesin 2007, 87). To be able to get to the lofty position of an agbasanko, the traditional Yoruba believed that one must have been properly acculturated in the norms and values of the society, and be ready to continuously learn at the feet of the wisdom of the young and old. This means that being an agbasanko is not even an end in itself such as would warrant the termination of the quest for learning from other people's experiences. Just as a Ph.D holder in the Western educational hierarchy, the award of the position of an agbasanko is simply an acknowledgement of exceptional effort by a person in the lifelong process of education.

Thus the Yoruba notion of education has as its cardinal focus the fostering of good character in the individual at every socially significant stage of his/her life, and making him/her a useful member of the community. The whole community is the "school", and the parents and other responsible members of the community primarily constitute the teachers. Education for the Yoruba is an all-inclusive process entailing character-building and acquiring cultural knowledge and skills in order to take an active part in the life of the community.

To be educated in the traditional Yoruba sense is therefore to have deservedly earned for oneself the appellation of omoluwabi, omogidi or agbasanko. The implication of the foregoing analysis is that education, for the Yoruba, is not an exclusive undertaking, but rather an inclusive, conscious and systematic process of developing innate potentialities and acquiring experiences for positive integrative social benefits. An elaborate picture of the traditional Yoruba understanding of an educated person reflecting all the inter-related attributes of omoluwabi, omogidi and agbasanko is given by J. A. Akinpelu:

The educated man can be described as one who combines expertise in some specific economic skills with soundness of character and skills with wisdom in judgment. $\mathrm{He}$ is who is equipped to handle successfully the problems of living in his immediate and extended family; who is well versed in the folklores and genealogies of his ancestors; who has skills to handle some minor health problems and where to obtain advice and help in major ones; who stands well with 
the ancestral spirits of the family and knows how to observe their worship; who has the ability to discharge his social and political duties; who is wise and shrewd in judgment; who expresses himself not in too many words but rather in proverbs and analogies leaving his hearers to unravel his thoughts; who is self-controlled under provocation, dignified in sorrow and restrained in success; and finally and most importantly, who is of excellent character (Akinpelu 1987, 178-179).

\section{The philosophical basis of traditional Yoruba notion of education}

The fundamental question that arises from the foregoing observations is: what are the basic philosophical principles that underlie the Yoruba conception of education? This question has not gained the attention of many scholars especially in African philosophical discourse, except for the recent analysis of Oladele Balogun (2008). Balogun rightly observes that the African conception of an educated person, in contrast to the Western conception, is characterized by the principles of "functionalism, social responsibility, job orientation, political participation and awareness, spiritual and moral values" (Balogun 2008, 123). This position deserves further reflection.

Education in traditional Yoruba culture was not a formal system as is the case with the modern Western one. Rather, it was informal and functional, with the aim of producing honest, respectable, skilled and socially responsible manpower that would conform to the social order of the day and contribute to its development. The people were guided in skill acquisition of varying types in accordance with what a particular community required and the natural environment in which the community lived. For instance, in coastal and riverside communities, skills taught included canoe construction, navigation, swimming, fish-netting, among others. In communities with thick forests and massive agrarian land, the skills taught were basically those of farming, hunting, communication, food preservation, weaving, among others. In short, for the traditional Yoruba, there was no homogenously operational curriculum. Instead, the natural environment in which a particular Yoruba community lived determined the kind of training its members received.

The Yoruba notion of education also has a social aspect, as distinct from the individualistic orientation of Western education. In the Yoruba world view, education 
does not stand in isolation from the society which established it. Since the community is the school, education draws inspiration and nourishment from the cultural values of the community; and in a symmetric fashion, the educated is expected to turn his acquired skill and knowledge into the growth, progress and development of the community. This element of social responsibility is quite understandable, given the communal nature of the traditional Yoruba society, where the educated were expected to contribute to the common good. This is the principle of progressivism in the Yoruba concept of education.

The principle of progressivism connotes a process of purposeful and positive transformation in a given direction, controlled by mutual and cooperative wills. It is an expression of a strong interconnection between human nature, human good and political community. The principle implies that human beings tend to perfect themselves, to grow and improve in certain directions that are better now than they were in the past, and will be better tomorrow. The principle of progressivism, as a pillar of the traditional Yoruba notion of education, stipulates that experience and knowledge should be used to create viable social structures for orderly social change.

Another fundamental principle underlying the Yoruba indigenous notion of education is moralism. Character training is central to the Yoruba practice of education. Unlike the Western idea of education where emphasis is usually on the cognitive aspect of man and the intrinsic value of knowledge to the neglect of the moral and other capabilities of man, the Yoruba notion of education is guided by moral concern and by the unwritten norms of the society. Morality is not only taught - it is lived. Thus courage is not only taught; it is demonstrated. Similarly, endurance and devotion to duty are not only taught; they are exhibited (Awoniyi 1995, 376). From childhood to adulthood, the person is taught morals by examples, direct instructions, proverbs, moon light folktales, myths, songs, etc.

Collectively therefore, the principles that informed traditional Yoruba education were functionalism, progressivism and moralism. 


\section{The problem of development in Africa}

The concept of development is susceptible to a variety of interpretations. In this context, we construe development as a process of transforming a state of being into a better state. More specifically, in the context of our reflections, development is a process of expanding, harnessing and adapting the capacity and material resources of a given society for the enhancement of the socio-economic, cultural, educational, technological and political well-being of its members. The problem of development in Africa is multi-dimensional in nature and scope. The causes of underdevelopment in Africa have been explained by many scholars on both externalist and internalist grounds.

The externalists such as Kwame Nkrumah (1965), Walter Rodney (1972), Obafemi Awolowo (1977), Ali Mazrui (1986) and Akinyemi Onigbinde (2003) argue that the problem of underdevelopment in post-colonial Africa is largely due to the impact of classical Western colonialism, and its extenuation through neo-colonialism. On the other hand, for the internalists such as Chinua Achebe (1998), Muyiwa Falaiye (1998), Olusegun Oladipo (2000), Claude Ake (2009) and A.K. Fayemi (2009b), the major cause of the poor state of development in Africa is the failure of leadership in the continent's post-colonial states.

While both the above accounts of the causes of Africa's under-development hold some truth, the point remains that the continent today is lagging behind every other continent in development. In view of the advancements taking place in other parts of the world hitherto characterized as third - world states along side Africa (such as Brazil, South Korea, Malaysia, Taiwan, Thailand, Singapore and India), the state of the continent's underdevelopment is alarming. The reality on the ground in many African states today is that political independence has brought no substantive positive change in the economic conditions and general well-being of the vast proportion of their populations (Fayemi 2009b, 106).

In Africa today, there is a palpable lack of basic infrastructure such as efficient transportation systems, piped water, electricity, housing, employment, health and educational facilities (Fayemi 2006, 62). This dismal condition is accentuated by the 
deteriorating standard of living on a daily basis through galloping inflation. Civil strife, poverty, corruption, diseases, malnutrition, illiteracy, political deceit, electoral fraud, social disorder (the list is endless) appear to be the only legacy that many African states are capable of passing from one generation to another. All these, together with the failure of African states to enhance human potentials needed for an integrative development, are clear indications of the horrendous state of affairs in the continent.

In the quest for a way out of Africa's current development quagmire, several approaches have been adopted by various African states, and a number of theories and recommendations have been offered by African and non-African social activists and scholars from diverse disciplinary backgrounds. One salient feature of most of these prescriptions is the conviction that education is a key tool for the continent's development. Nevertheless, the critical question is, has education been a true catalyst of development in Africa?

\section{Contextualizing education for development in Africa: The Nigerian Experience}

As in other parts of the world, many people in Africa strongly believe that education is pivotal to integrated development. They are convinced that an increase in the number of educated personnel in the continent is ipso facto an increase in her level of human development (Balogun 2008, 124). Nevertheless, the centrality of education for development is a mere slogan in many African states, and will remain so for a long time unless urgent measures are taken to reverse the lip-service given to this truth.

In Nigeria's National Policy on Education (1998), it is stated that education is a tool to achieve the national objectives of national unity, self-reliant citizens and economy, enlightened citizens, capacity building and integrated national development. Since political independence in 1960, Nigeria has expressed very strong faith in education as a potent tool for eradicating underdevelopment and its consequences such as illiteracy, disease, malnutrition, unemployment, socio-economic and political 
instability, superstitious beliefs and practices, avarice, greed, tribalism, nepotism and ethnicity (Ajayi 1995, 199).

However, the extent to which education has been a pivot to achieving all these laudable objectives today is highly questionable. This is due to some challenges confronting the country's education system.

First, the education system in Nigeria is a mirror of the unsatisfactory conditions of social life and general underdevelopment plaguing the nation. Education cannot perform any magic under this perilous state of affairs. The Nigerian education system is confronted by many problems: disparities in educational development along geographical, cultural, ethnic, religious and gender lines, inadequate funding by government and infrastructural decay, examination malpractices, indiscipline, frequent strikes by academic and non academic staff of various educational institutions, teachers' insensitivities and incompetence, among others (Fayemi 2009c, 3-4). The negative effects of all these problems on human capacity building for development are easy to see.

Second and more fundamental, due to the Western model of education which Nigeria's education system is uncritically patterned after, Nigeria is plagued by a distorted conception of education which has fostered new problems, both at the level of policy formulation and policy implementation at different educational levels. Concerning this Balogun has stated:

The values attached to the Western supposed conception have made African to embrace and extol beyond normalcy, the idea of an educated man as associated with being bookish, prowess and what have you. Marred in this conceptual distortion, African emphasis has been on formal education at the total expense of other qualities that make an educated man. The belief is that the more the formal educational institutions, the more the educated personnel in Africa. However, an increase in the emphasis on formal education has failed to be commensurate with an increase in truly educated personnel in the continent... But where there is dearth of truly educated fellows, then, it is no surprise that development is eluding the African continent. This is the rationale behind the failure of education being in reality, a pivot for social change [and development] in Africa (Balogun 2008, 125). 
Notwithstanding the salience of Balogun's remarks, it would be superfluous to blame in entirety our current educational predicament on Western education which came as a handy tool of colonialism. This is particularly so when cognizance is given to the fact that for several decades now, Africans themselves have been in charge of the educational systems of their countries. Whether (and why) they are still advertently or unavoidably tied to the imperialistic apron strings in their administration of education in their respective states is a different question.

However, in line with Balogun's position, we see the failure of education in Africa today not because it inherently lacks the capacity to unlock the doors of development, but essentially because of our flawed conception of education, its philosophy and its goals. In view of this, our commitment cannot but be shoddy. Fundamentally therefore, the bane of African under-development today is not explainable purely in terms of material depravation, whether externally induced through imperialism or internally occasioned by bad leadership.

Ultimately therefore, at the core of the problem of underdevelopment in Africa today is the poverty of the African mind. This poverty is fuelled by the continued failure of our education systems to nurture the inherent inquisitive and critical attitudes of our people in the making of rational choices among competing indigenous and foreign ideas, values and principles with which they are daily confronted. What, then, can we do to truly make education a tool of development in Africa?

\section{Philosophical relevance of the traditional Yoruba notion of education to development in Twenty-first century Africa}

The traditional Yoruba notion of education has some lessons from which contemporary African states can learn in their quest for development. The functionalism, progressivism and moralism, greatly emphasised in this model of education, are important elements of integrative development. The dictum of education for development, which many African states subscribe to as a political gimmick, can only cease to be utopian if indigenous notions of education such as the Yoruba one are reinvigorated into the consciousness of contemporary Africans. 
Accordingly, such an indigenous orientation will bring an attitudinal change among the citizens that will limber up our developmental drive (Balogun 2008, 126).

Contemporary African states in general and educational systems in particular can benefit from the functionalist nature of education in traditional Yoruba society. Contrary to the current trend of having a homogenous educational curriculum across different regions of a state without due regard to the peculiar natural resources of each region, traditional Yoruba education was cognizant of this important factor. Creativity and professionalism are implied in the educational principle of functionalism, as it does not allow covetous consumption of theories without understanding their relationship to concrete human realities. It stresses the need to make educational curricular relevant to human capacity building in order to address pressing social, economic and environmental challenges.

The philosophical principle of progressivism was an inspiration for development in traditional Yoruba societies: leaders and followers were passionately concerned about the development of their respective communities. Development for them was never conceived in purely material terms as is the case with contemporary Western theories of development. Rather, development for them meant ilosiwaju (the improvement of existing social conditions). This conception of development revealed an inherent relationship both with the past and the future (Oluwole 1997, 145). More fundamentally, it entailed "the development of human character, which determines competence in the management of human affairs" (Oluwole 1997, 146). Through education, the individual learnt to pursue his/her own objectives as a means to advancing societal interests. Thus education in Yoruba culture was integratively progressive. The lesson implicit in the principle of progressivism in traditional Yoruba education, from which contemporary Africa can learn, is that the government, teachers, students and other stakeholders in the education system must see education not as an end in itself for their personal gains alone, but rather as a tool for developing the society and advancing the course of humanity.

At the root of our pervasive gridlock is a moral crisis which can only be addressed by education as practiced in traditional societies such as that of the Yoruba. In those societies, People were taught the value of hard work, diligence, self-reliance, and the 
importance of acquiring character traits such as honesty and social responsibility. It was with the advent of Western education in Africa that the concern for character formation became intensely de-emphasized, and the crass for paper qualifications became phenomenal. While we have been lured into believing that it is only through a Western-type formal school system that social and economic development can be achieved, the truth is that it is only in the hands of morally upright individuals that such education is an effective instrument for development. This becomes clear when we consider that many modern crimes such as fraud based on information technology can only be executed by people with high qualifications in Western-type formal education.

On the whole, we are of the conviction that the traditional Yoruba notion of education is relevant to contemporary educational practice, and, in particular, to the African quest for development. This conclusion is likely to be greeted with protest from those who believe in the supposed dichotomy of tradition and modernity, and in the superiority of the latter over the former. The premise of their argument is that while traditional notions of education might have served pre-colonial African societies well, the challenges of our day are too excruciating to be effectively confronted by knowledge and skills acquired from such a cultural milieu.

However, the criticism above is based on a false conception of "tradition" to mean absolute allegiance to long-established patterns of thought, values, institutions and social practices that define a people's identity. Nevertheless, we do not conceive tradition as a fixed product with no relevance to contemporary realities; rather, we see tradition as more of an evolutionary process. As Segun Gbadegesin correctly observed, "the significance of continuity in the culture and institutions of people cannot be overstated, and this is what tradition assures" (Gbadegesin 2008, 40). Thus contemporary African societies should exploit the enormous potential that traditional notions of education have for providing direction in the formulation of appropriate educational policies. Such notions could also serve as a basis upon which to fashion an authentic contemporary African philosophy of education.

We also recognize that the principles underlying traditional Yoruba education considered alone may be insufficient for bringing about integrated development in 
contemporary Africa. It is for this reason that we propose that those principles complement the defining elements of Western education now prevalent in Africa. This synthesis of indigenous principles of education with the scientific and humanistic ideas of Western education would foster the realization of remarkable development in the continent.

\section{Conclusion}

In the foregoing discussion, we have sought to undertake a critical examination of the relevance of the traditional Yoruba concept of education to the contemporary African quest for development. The Ghanaian philosopher, Kwasi Wiredu (1980), observes that there are some anachronistic elements in African traditions that must be eradicated in our day. We do not think that the traditional Yoruba notion of education constitutes an anachronism, as it is potently capable of contributing to development in contemporary Africa.

Paipai Obanya (2004) has correctly pointed out that education should aim at two mutually inclusive goals: conservation and transformation. For Obanya, conservation entails acculturation - the focused passing on of a community's skills, knowledge and attitudes from one generation to the next. Conservation also involves the utilization of indigenous African educational principles to meet the continents current development needs. On its part, transformation is receptiveness to novel scientific, technological and educational ideas from non-African cultures, with the aim of integrating each person, each state and the entire continent into the wider horizon of a fast changing world. For meaningful development to take place in twenty-first century Africa, we must begin to jointly and appropriately pursue the vital goals of conservation and transformation in our formulation of educational policies. The role of the government and all other stakeholders in making this a reality cannot be over-emphasised. Their failure to invest in appropriate education as a foundation of development would be a great disservice to the continent. 


\section{References}

Achebe, C. 1983. The Trouble with Nigeria. Enugu: Fourth Dimension Publishers.

Ajayi, K. 1995. Reflections on the Nigerian Education System: A College Provost's Perspective. Abeokuta: Osiele Consult Services, F.C.E.

Akinpelu, J.A. 1987. An Introduction to Philosophy of Education. London: Macmillan Publishers.

Ake, C. 2001. Democracy and Development in Africa. Ibadan: Spectrum Books.

Awoniyi, T.A. 1975. "Omoluwabi: The Fundamental Basis of Yoruba Traditional Education". In Abimbola, Wande ed. Yoruba Oral Tradition. Ibadan: Ibadan University Press.

Awolowo, Obafemi. 1977. The Problems of Africa: The Needs for Ideological Reappraisal. London: Macmillan Educational Books Limited.

Balogun, O.A. 2008. "The Idea of an 'Educated Person' in Contemporary African Thought". Journal of Pan African Studies, Vol.2 No.3, 2008, pp.117-128.

--. 2009. "In Defense of the 'Living -dead' in traditional African thought: The Yoruba Example". Philosophia: International Journal of Philosophy, Vol.38 No.1, pp.10-12.

Fafunwa, A.B. 1982. "African Education in Perspective". In Fafunwa, A.B. and J.U. Aisiku eds. Education in Africa: A Comparative Survey. London: George Allen and Unwin Ltd.

Falaiye, M. 1998. “African Democracy: Its Problems”. In Dukor, Maduabuchi ed. Philosophy and Politics: Discourse on Values and Power in Africa. Lagos: Obaroh \& Ogbinaka.

Fayemi, A. K. 2006. "The Tragedy of Pseudo-democracy and Social Disorder in Contemporary Africa: Any Philosophical Recue?" In Odimegwu, Ike ed. Philosophy and Africa. Amawbia: Lumus Nig. Ltd.

--. 2009a. "Human Personality and the Yoruba Worldview: An Ethico-Sociological Interpretation". The Journal of Pan African Studies, Vol.2 No.9, pp. 166-176.

--. 2009b. "A Philosophical Appraisal of Leadership and Development in Nigeria". In Edoh, Tony and Terhemba Nuam eds. Democracy, Leadership and Accountability in Post-Colonial Africa: Challenges and Possibilities. Makurdi: Aboki Publishers.

--. 2009c. "The Role of Philosophy of Education in the Development of Nigerian Educational System". Eko Journal of Educational Research, Vol.2 No.3, pp.114.

Federal Republic of Nigeria. 1998. National Policy on Education (Revised). Lagos: Federal Government press.

Gbadegesin, S. 1991. African Philosophy: Traditional Yoruba Philosophy and Contemporary African realities. Chicago: Gateway.

--. 2007. "In Search of Agbasanko". The Nation Newspaper, Friday September 28, 2007, p.87.

--. 2008. "Problematizing Tradition". The Nation Newspaper, August 22, 2008, p.40.

Horton, R. 1970. “Traditional Thought and Western Science”, in Wilson, B.R. ed. Rationality. Oxford: Blackwell, pp.153-164.

Kalusi, J.I. 2007. "Educational Reform and National Development in Nigeria". Nigerian Journal of Educational Philosophy, Vol.20 No.3, pp.1-6.

Levy-Bruhl, L. 1967. La Mentality Primitive. London: Allen and Unwin. 
Majasan, J.A. 1967. "Yoruba Education: Its Principles, Practice and Relevance to Current Educational Development". Unpublished PhD Thesis, University of Ibadan, Nigeria.

Mazrui, Ali. 1986. The Africans. London: BBC Publications.

Nkrumah, K. 1965. Neocolonialism: The Last Stage of Imperialism. London: Heinemann.

Obanya, P. 2004. The Dilemma of Education in Africa. Ibadan: Heinemann Educational Books.

Oladipo, O. 2000. "Leadership, Structures and Social Transformation in Nigeria". Current Viewpoint: A Review of Culture and Society, Vol.2 No.1, pp.82-90.

Oluwole, S.B. 1997. "The Labyrinth Concept of time as basis for Yoruba view of Development". Studies in Intercultural Philosophy, Vol.8, pp.139-150.

--. 2006. "Introduction to African Philosophy". In Asanju, Dapo F. ed. General Studies Book of Readings: Philosophy, Science and Technology, Vol.3. Lagos: Lagos State University press.

--. 2007. "Who are (We) the Yoruba?" A key note paper delivered at a Pre-World Philosophy Day Conference, June 12, at the National Theatre, Lagos.

Onigbinde, A. 2003. Development of Underdevelopment: Conceptual lessons in Political Economy. Ibadan: Front line Publications Ltd.

Rodney, W. 1972. How Europe Underdeveloped Africa. Dares-Salam: Tanzania Publishing House Ltd.

Wiredu, K. 1980. Philosophy and an African culture. Cambridge: Cambridge University Press. 